\title{
A Review on Analytical Techniques for the Quantification of Dolutegravir - An Integrase Strand Transfer Inhibitor
}

\section{Thotakura Sai Pavan*, Naresh Panigrahi and Mukthinuthalapati Mathrusri Annapurna}

GITAM Institute of Pharmacy, GITAM (Deemed to be University), Visakhapatnam, India

*Corresponding Author: Thotakura Sai Pavan, GITAM Institute of Pharmacy, GITAM (Deemed to be University), Visakhapatnam, India.
Received: January 30, 2021

Published: February 17, 2021

(C) All rights are reserved by Thotakura Sai

Pavan., et al.

\begin{abstract}
Dolutegravir is a novel integrase stand transfer inhibitor active against human immunodeficiency virus. Dolutegravir is an integrase strand transfer inhibitor which preferentially blocks the strand transfer step of integration of the viral genome into the host cell's DNA mediated by the viral integrase enzyme. The authors have reviewed the analytical methods developed for the estimation of Dolutegravir in pharmaceutical dosage forms and in biological samples in the present paper.
\end{abstract}

Keywords: Dolutegravir; Integrase Strand Transfer Inhibitor; DNA

\section{Introduction}

Dolutegravir is chemically (4R,12aS)-N-(2,4-difluorobenzyl)7-hydroxy-4-methyl-6,8-dioxo-3 4,6, 8,12,12a-hexahydro-2H-pyrido[1',2':4,5]pyrazino[2,1-b][1,3] oxazine-9-carboxamide $\left(\mathrm{C}_{20} \mathrm{H}_{18} \mathrm{~F}\right.$ ${ }_{2} \mathrm{~N}_{3} \mathrm{NaO}_{5}$ ). Dolutegravir is an integrase strand transfer inhibitor [1]. Dolutegravir sodium is a white to light yellow powder and is slightly soluble in water and methanol and is rapidly absorbed after oral administration and it was approved by FDA. Dolutegravir is active against HIV type 1 and also has some in vitro activity against HIV type $2[2]$.

Dolutegravir blocks the strand transfer step of the integration of the viral genome into the host cell and prevents HIV from replicating and lowers the amount of HIV in the blood. Dolutegravir will not cure or prevent HIV infection or AIDS, however, it helps keep HIV from reproducing and appears to slow down the destruction of the immune system.

Dolutegravir is available as tablets with brand name Instgra (Labelled claim $50 \mathrm{mg}$ ) from Avalon Pharma Pvt Ltd (India). Dolutegravir is also available in combination with Rilpivirine (Juluca) (Labelled claim: Dolutegravir: $50 \mathrm{mg}$ and Rilpivirine: 25 $\mathrm{mg}$ ) as film coated tablets; Lamivudine (Dovato) (Labelled claim: Dolutegravir: $50 \mathrm{mg}$ and Lamivudine: $300 \mathrm{mg}$ ); Lamivudine and Tenofovir Disoproxil Fumarate (Viropil) (Labelled claim: Dolute- gravir: $50 \mathrm{mg}$, Lamivudine: $300 \mathrm{mg}$ and Tenofovir Disoproxil Fumarate: $300 \mathrm{mg}$ ).

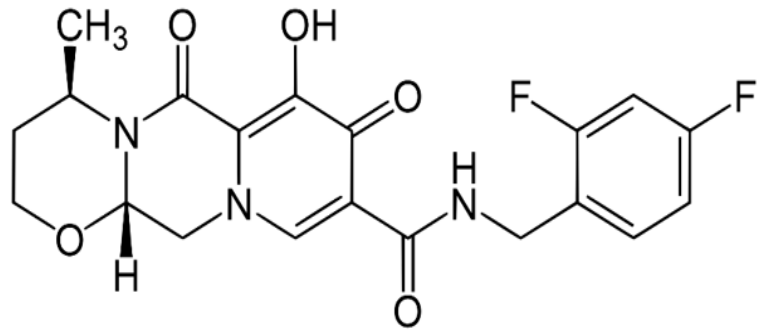

Figure 1: Structure of Dolutegravir.

The authors have summarised the analytical methods so far developed in the literature for the determination of Dolutegravir in the present review article. The methods include are spectrophotometry [4-7], HPLC [8,9], HPTLC [10] (Table 1) for the pharmaceutical formulations. Liquid chromatographic methods were also developed for the separation of optical isomers of Dolutegravir $[11,12]$ and for the estimation of Dolutegravir in human plasma using HPLC [13], UPLC [14] and LC-MS/MS [15]. 


\begin{tabular}{|c|c|c|c|c|}
\hline Reagent & $\begin{array}{l}\text { Linearity }(\mu \mathrm{g} / \\
\mathrm{ml})\end{array}$ & $\lambda_{\max }(\mathrm{nm})$ & Comment & Ref \\
\hline \multicolumn{5}{|l|}{ Spectrophotometric methods } \\
\hline Water & $5-40$ & 259.8 & - & 3 \\
\hline $\begin{array}{l}\text { Ferric chloride and } \\
1,10- \\
\text { Phenanthroline reagent }\end{array}$ & $40-140$ & 520 & $\begin{array}{l}\text { Orange red } \\
\text { complex }\end{array}$ & 4 \\
\hline $0.8 \mathrm{M}$ aq. Urea & $2.5-20$ & $\begin{array}{c}258 \\
248-268 \\
\quad 256\end{array}$ & $\begin{array}{c}\lambda_{\text {ma }} \\
\text { AUC } \\
\text { First derivative }\end{array}$ & 5 \\
\hline Water & $2-18$ & 259 & - & 6 \\
\hline Water & $5-40$ & 259.8 & - & 7 \\
\hline \multicolumn{5}{|l|}{ Liquid chromatographic methods } \\
\hline $\begin{array}{l}0.1 \% \text { Aq. Trifluoro acetic acid: } \\
\text { Methanol }\end{array}$ & $0.076-1.5$ & 240 & $\begin{array}{l}\text { HPLC (Gradient } \\
\text { mode) }\end{array}$ & 8 \\
\hline $\begin{array}{l}\text { Dipotassium } \\
\text { hydrogen orthophosphate: } \\
\text { Methanol (70:30), }\end{array}$ & $50-150$ & 260 & HPLC & 9 \\
\hline $\begin{array}{l}\text { Acetonitrile: water (pH } 7.5)(80: 20) \\
\text { Methanol: } \\
\text { Chloroform: } \\
\text { Formic acid (8: } 2: 0.5)\end{array}$ & $\begin{array}{c}5-35 \\
200-900 \mathrm{ng} / \\
\text { spot }\end{array}$ & $\begin{array}{l}260 \\
265\end{array}$ & $\begin{array}{l}\text { HPLC } \\
\text { HPTLC }\end{array}$ & 10 \\
\hline $\begin{array}{l}\text { Acetonitrile: water: ortho phosphoric } \\
\text { acid }\end{array}$ & $\begin{array}{c}0.161-2.276 \\
\text { (Enantiomer) } \\
0.195-2.180 \\
\text { (Diastereomer) }\end{array}$ & 258 & $\begin{array}{l}\text { Chiral HPLC } \\
\text { Stability } \\
\text { indicating }\end{array}$ & 11 \\
\hline $\begin{array}{l}\text { Phosphate buffer (pH 2.0): Solvent } \\
\text { mixture (63: 37) } \\
\text { Solvent mixture: tert-butyl methyl } \\
\text { ether: Acetonitrile (10:35) }\end{array}$ & & & Chiral HPLC & 12 \\
\hline $\begin{array}{l}20 \text { mM Sodium acetate buffer ( } \mathrm{pH} 4.0) \text { : } \\
\text { Methanol (30: 70) }\end{array}$ & $0.102-7.004$ & 254 & $\begin{array}{c}\text { HPLC } \\
\text { Human plasma }\end{array}$ & 13 \\
\hline $\begin{array}{l}50 \mathrm{mM} \text { Formic acid and } 50 \mathrm{mM} \text { Ammo- } \\
\text { nium acetate: Acetonitrile }\end{array}$ & $0.25-10$ & 258 & $\begin{array}{c}\text { UPLC } \\
\text { Plasma } \\
\text { Gradient mode }\end{array}$ & 14 \\
\hline Acetonitrile: $0.1 \%$ Formic acid & $0.005-10$ & - & $\begin{array}{l}\text { LC-MS/MS } \\
\text { Human plasma }\end{array}$ & 15 \\
\hline
\end{tabular}

Table 1: Review of analytical methods for the determination of Dolutegravir. 


\section{Conclusion}

The present review article helps the readers to do research in a new field apart from the presenting existing analytical techniques for the anti-viral drug Dolutegravir.

\section{Bibliography}

1. Pommier Y., et al. "Integrase inhibitors to treat HIV/AIDS". Nature Reviews Drug Discovery 4.3 (2005): 236-248.

2. Castellino S., et al. "Metabolism, excretion, and mass balance of the HIV-1 integrase inhibitor Dolutegravir in humans". Antimicrobial Agents and Chemotherapy 57 (2013): 3536-3546.

3. Girija BB., et al. "Development and validation of UV spectrophotometric method for estimation of Dolutegravir Sodium in tablet dosage form". Malaysian Journal of Anal Sciences 19.6 (2015): 1156-1163.

4. Swathi Naraparaju., et al. "Spectrophotometric quantification of Dolutegravir based on redox reaction with Fe3+/1, 10-phenanthroline". Future Journal of Pharmaceutical Sciences 6.107 (2020).

5. Masthanamma SK., et al. "A novel UV-spectrophotometric method development and validation of Dolutegravir in bulk and its laboratory synthetic mixture by using $8 \mathrm{~m}$ urea as hydrotropic solubilizing agent". International Journal of Pharmaceutical Sciences and Drug Research 7.4 (2015): 370-375.

6. Bhavyasri K and Divya E. "Method Development, Validation and Forced Degradation Studies of Dolutegravir, An Anti-Retroviral Drug using UV-Visible Spectroscopy". International Journal of Pharma Sciences and Scientific Research 5.6 (2019): 69-74.

7. Balasaheb., et al. "Development and validation of UV- spectrophotometric method for estimation of Dolutegravir sodium in tablet dosage form". Malaysian Journal of Analytical Sciences 19.6 (2015): 1156-1163.

8. Venkatnarayana M and Siva Jyothi. "Development of validation and stability indicating method of anti-HIV Dolutegravir drug and its related impurities by using RP-HPLC". Journal of Chromatography and Separation Techniques 11 (2020): 426.

9. Murali Krishna PV., et al. "Analytical method development and validation by new RP-UPLC method for the determination of Dolutegravir sodium in tablet dosage form". International Journal of Pharmaceutical Research and Analysis 8.2 (2018): 22-25.
10. Bhavar GB., et al. "High-Performance Liquid Chromatographic and High-Performance Thin-Layer Chromatographic Method for the Quantitative Estimation of Dolutegravir Sodium in Bulk Drug and Pharmaceutical Dosage Form". Scientia Pharmaceutica 84.2 (2016): 305-320.

11. Chandrashekar Reddy K., et al. "Stability-indicating HPLC method for the quantification (4S, 12R)-enantiomer and (4R, 12S)-diastereomer in Dolutegravir Sodium". International Journal of Pharmacy and Pharmaceutical Research 9.2 (2017): 52-63.

12. Yashpalsinh NG., et al. "Development and validation of chiral RP-HPLC method for quantification of optical isomers in Dolutegravir sodium". Der Pharmacia Lettre 10.9 (2018): 90100.

13. Satyadev TNVSS., et al. "Development and validation of HPLC method for the determination of Dolutegravir in human plasma". Der Pharmacia Sinica 6.4 (2015): 65-72.

14. Wang X., et al. "A validated method for quantification of Dolutegravir using ultra-performance liquid chromatography coupled with UV detection". Therapeutic Drug Monitoring 38.3 (2016): 327-331.

15. Chantelle-Bennetto-Hood GT., et al. "A sensitive HPLC-MS/ MS method for the determination of Dolutegravir in human plasma". Journal of Chromatography B: Analytical Technologies in the Biomedical and Life Sciences 15 (2014): 225-232.

\section{Assets from publication with us}

- Prompt Acknowledgement after receiving the article

- Thorough Double blinded peer review

- Rapid Publication

- Issue of Publication Certificate

- High visibility of your Published work

Website: $\underline{w w w . a c t a s c i e n t i f i c . c o m / ~}$

Submit Article: www.actascientific.com/submission.php

Email us: editor@actascientific.com

Contact us: +919182824667 